\title{
Relationships between sheep liveweight production and dry matter yield for lucerne-based pastures in spring
}

\author{
Annamaria MILLS, Malcolm C. SMITH and Derrick J. MOOT* \\ Lincoln University, Field Research Centre, PO Box 85084, Lincoln University 7647, Canterbury, New Zealand \\ *Corresponding author: Derrick.Moot@lincoln.ac.nz
}

\begin{abstract}
A five-year dryland grazing experiment explored the relationship between sheep liveweight (LWt) production and dry matter (DM) yield of lucerne-based pastures in spring. In 2011, a randomised complete block experiment with a lucerne monoculture, a lucerne/brome mix and a lucerne/cocksfoot mix were established at Ashley Dene, Canterbury and replicated six times. Pastures were managed under dryland conditions. Ewes with twin lambs at foot grazed in spring and LWt production, DM yield and botanical composition were quantified.

Regression analysis showed total DM feed on offer accounted for only $11 \%$ of the observed variation in spring LWt production. Subsequent analysis of the botanical composition of the three pastures showed total feed on offer in spring was unaffected by pasture treatment in four out of five years. However, yield of the lucerne component on offer was $77-230 \%$ greater in the monoculture than the mixes in Years 3-5. Brome yields declined from Year 3 and did not recover. By Year 5, weeds accounted for $41 \%$ of the feed on offer in spring in the lucerne/brome mix.

Net spring ewe + lamb liveweight production increased at a rate equivalent to $246 \mathrm{~kg} \mathrm{LWt}+71 \mathrm{~kg} \mathrm{LWt}$ per tonne of lucerne DM on offer $\left(\mathrm{R}^{2}=0.83\right)$. There was no effect of pasture type. Where possible lucerne should be established as a monoculture to maximise liveweight gain. A runout stand was overdrilled with a companion grass to extend the productive stand life. The loss of lucerne over time indicated renewal should be initiated within 2-3 years of oversowing to ensure LWt production is not compromised.
\end{abstract}

Keywords: alfalfa, Bromus spp., Dactylis glomerata, Medicago sativa, orchardgrass

\section{Introduction}

The 'MaxLucerne' dryland grazing experiment was established to provide information for farmers with large areas of grazed lucerne (Medicago sativa L.). One issue consistently raised at lucerne field days has been a potential feed deficit between animal demand and lucerne growth in early spring (late pregnancy and early lactation). This has been addressed previously through the use of more winter cropping but can be seen as an impediment to using more lucerne (Stevens et al. 2012). One suggestion is to use lucerne/grass mixes, which have been researched since the 1960s (Cullen 1960; O'Connor 1967; Vartha 1967; Fraser 1982). However, these studies have generally focussed on the pasture with limited sheep liveweight (LWt) data collected. To address these concerns, a comparison of grazing lucerne as a monoculture compared with two contrasting lucerne/grass (Luc/grass) mixtures was undertaken. For this experiment, LWt production was examined in relation to yield and composition changes in the pasture treatments over a 5-year period. Bromes (Bromus spp.) were selected as companion species because of their late-winter/early-spring growth and their potential to increase feed supply in the early-spring pinch period. In contrast, cocksfoot (Dactylis glomerata) was selected as it has previously been shown to be highly persistent in dryland east coast environments (Mills et al. 2014) where water stress occurs in most years but varies in duration and severity. It is also commonly used in commercial mixes with lucerne.

Annual LWt production, weighted seasonal mean daily LWt gains per head for all stock classes, DM feed on offer annually and seasonal pasture composition are fully explained in Moot et al. (2019). The research reported here quantifies net LWt production (ewes + twin lambs), dry matter (DM) feed on offer and the impact of changes in pasture composition over five years in the crucial spring period. These data are used to examine the relationships, between animal and plant production before pasture growth rates decline in a summer dry environment.

\section{Materials and Methods}

Full details of the experiment, including stock classes, grazing periods, changes in stocking rate and grazing days are reported in Moot et al. (2019) and are briefly summarised.

The 'MaxLucerne' dryland grazing experiment was established at the Ashley Dene Pastoral Systems Research Farm, Canterbury (172 19'25.23”E; 4339'0.60”'S; 40 m a.s.1.). Soils (Typic Dystrustept, USDA taxonomy) underlying the 17.7 ha site varied. Depth to alluvial gravels ranged from $<20 \mathrm{~cm}$ (Lowcliffe stony silt loam soil) to $>90 \mathrm{~cm}$ (Ashley Dene deep fine sandy loam soil). This affected soil 

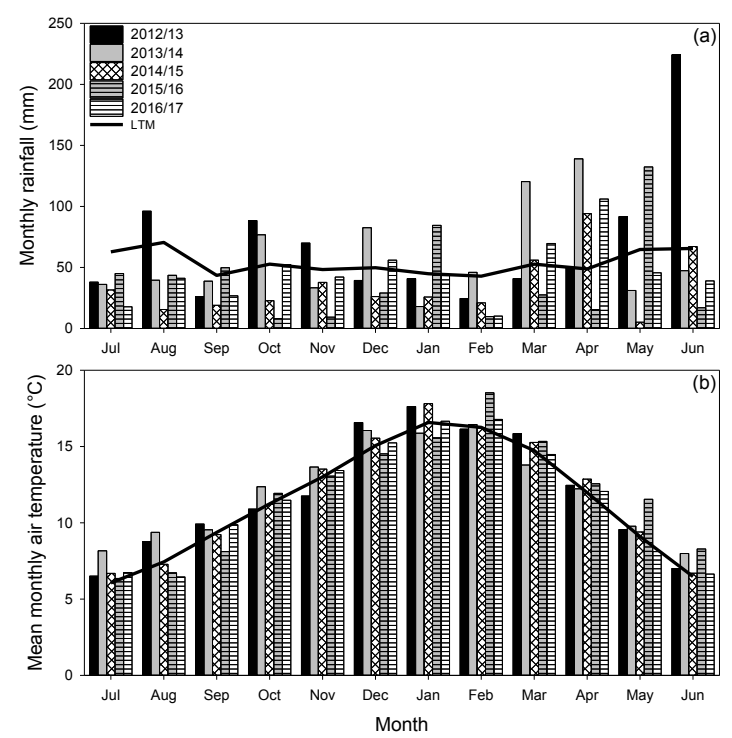

Figure 1 Monthly (a) rainfall and (b) mean air temperature between Year 1 (2012/13) and Year 5 (2016/17) at Ashley Dene, Canterbury. Long-term means (LTM; 1970-2010) are shown as a solid black line. LTM rainfall was recorded at Burnham and LTM temperature at Broadfields.

water holding capacity in the top $1.0 \mathrm{~m}$ of soil which is $60-80 \mathrm{~mm}$ to $100-160 \mathrm{~mm}$, respectively (McLenaghen $\&$ Webb 2012).

A randomised complete block experiment was established from November 2011. The three pastures were a lucerne monoculture (Luc), a lucerne/brome mixture (Luc/Brome) and a lucerne/cocksfoot mixture $(\mathrm{Luc} / \mathrm{CF})$. There were six replicate paddocks of each treatment with central laneways to facilitate stock movement. An age structure was created by overdrilling a runout lucerne stand for two replicates. However, subsequent analysis indicated age structure had no effect on results ( $\mathrm{P}=0.77$ to $\mathrm{P}=0.82)$ and so it is not discussed. A cultivar from each of two species of brome ('Atom' prairie grass (Bromus willdenowii) or 'Bareno' pasture brome (Bromus valdivianus)) and two cultivars of cocksfoot ('Vision' or 'Safin'; Dactylis glomerata) were sown (three replicates of each). Annual and seasonal yield differences among companion grass cultivars are reported in Moot et al. (2019) and species differences are reported here. Measurements of ewe + lamb LWt, feed on offer and botanical composition were made from Year $1(2012 / 13)$ to Year $5(2016 / 17)$. Observations were terminated in the runout pastures in autumn of Year 4 (Reps 3 and 4). Individual paddocks ranged from 0.60 to 1.30 ha in size.

Winter weed control was used in the monoculture following recommended commercial practice. No herbicides were applied in the Luc/grass mixes.

\section{Environmental conditions}

Long-term mean (LTM) rainfall was recorded at Burnham ( $\sim 3 \mathrm{~km} \mathrm{NE}$ of the experimental area) and LTM temperature at Broadfields ( 12 km NE) which were the two closest sites with long-term data available on the NIWA CliFlo database (https://cliflo.niwa.co. $\mathrm{nz} /$ ). Monthly rainfall and mean air temperature during the experimental period are shown in relation to the long-term means (1970-2010) in Figure 1. Annually, rainfall ranged from 422 (Year 3, 2014/15) to $830 \mathrm{~mm}$ (Year 2, 2013/14) compared with the LTM at Burnham of $643 \mathrm{~mm}$. The LTM for the July-November spring period, which this paper focusses on, was $278 \mathrm{~mm}$. Actual rainfall ranged from a minimum of $127 \mathrm{~mm}$ (Year 3) to $319 \mathrm{~mm}$ (Year 1). In Year 2, $227 \mathrm{~mm}$ of rain fell between July and November. However, this followed $224 \mathrm{~mm}$ of rain which fell in June 2013, which had fully recharged the shallow soil profile, leading to wet conditions underfoot.

\section{Stock management}

Lambing start and finish dates varied from year to year, and among treatments. Initial lambing start dates ranged from 14/08 in Year 3 to 10/9 in Year 5. Ewes with twin lambs at foot grazed the pastures until weaning in Years 1 and 2. In Years 3-5, weaning occurred 1-2 weeks after pastures had been destocked due to lack of feed in experimental treatments. Based on weaning date alone, the minimum age of a lamb at weaning was 61 days (Year 5) and the maximum was 98 days (Year 3). Predominantly, Coopworth sheep grazed the pastures.

Sheep mobs were not replicated. Each mob grazed the six replicate paddocks of their allocated pasture treatment rotationally. A 'put and take' system matched feed supply and animal demand so stocking rates varied (Moot et al. 2019). Over the five years the average mob size (ewes + twin lambs), when rotational grazing was initiated, ranged between 61 and 80 animals/mob. This represented initial average stocking rates of 10 to 14 ewes/ha plus their lambs. In spring, a weighted seasonal LWt gain was calculated for each stock class. These data, in combination with grazing days per plot, were used to calculate LWt production per hectare. Here, net spring LWt production is the sum of LWt produced by ewes and their twin lambs prior to weaning or destocking.

In Year 2, wet conditions under foot led to development of foot scald. Stock were treated three times with $8 \%$ zinc sulphate solution in foot baths. Vaccines for oxoplasmosis, campylobacter and drenches for gastrointestinal worms were given following recommended industry practice.

\section{Statistical analysis}

Yield and botanical composition data were analysed by 


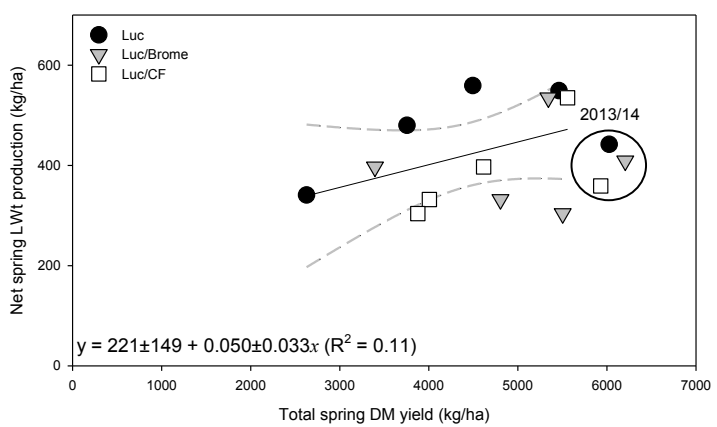

Figure 2 Net spring liveweight (LWt) production (kg/ ha) against total spring DM yield for Luc, Luc/ Brome and Luc/CF pastures between 2012/13 and 2016/17 at Ashley Dene, Canterbury. Note: 2013/14 data (circled) were excluded from analysis due to poor livestock performance resulting from foot scald.

ANOVA (Genstat v.18, VSN International Ltd). Where significant, means were separated by Fisher's protected LSD at the $\alpha=0.05$ level. However, where the results were deemed important to understanding the emerging patterns, or where a high degree of variability was observed, trends $(\mathrm{P}<0.1)$ are also discussed. Regression analysis was used to explore the relationships between net spring LWt production and total DM or lucerne DM on offer among pasture treatments. Foot scald resulted in lower than expected LWt production in Year $2(2013 / 14)$ and these data were excluded from the regression analysis to prevent confounding, but are shown for completeness. Analysis was performed on treatment mean data with grouped linear regression used to determine if differences existed in slopes or intercepts among pasture treatments.

\section{Results}

\section{Relationship between LWt production and total feed on offer in spring}

The relationship between total spring feed on offer and net LWt production from lactating ewes with twin lambs at foot was poor. Only $11 \%$ of the observed variation was accounted for (Figure 2) and no effect of pasture treatment occurred. To explore this failure of total yield to explain differences in spring LWt production, botanical composition was analysed.

\section{Spring DM production and botanical composition}

Over the five growth seasons, total spring feed on offer ranged from $3010 \pm 321 \mathrm{~kg} \mathrm{DM} / \mathrm{ha}$ from Luc and Luc/ Brome pastures (Year 3; 2014/15) to $6055 \pm 264 \mathrm{~kg} \mathrm{DM} /$ ha in spring of Year $2(2013 / 14)$ when all three pastures produced similar DM yields (Figure 3). Total feed on offer in spring was unaffected by pasture treatment in Years $1(5455 \pm 125 \mathrm{~kg} / \mathrm{ha}), 2(6055 \pm 264 \mathrm{~kg} \mathrm{DM} / \mathrm{ha}), 4$ $(4435 \pm 466 \mathrm{~kg} \mathrm{DM} / \mathrm{ha})$ and $5(4380 \pm 553 \mathrm{~kg} \mathrm{DM} / \mathrm{ha})$.

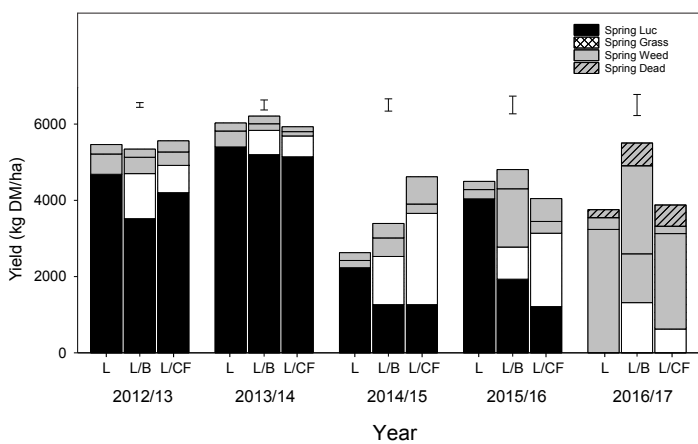

Figure 3 Spring DM yield from lucerne (Luc), sown companion grass, weed and dead components of lucerne monocultures (L), lucerne/brome (L/B) and lucerne/cocksfoot (L/CF) pastures at Ashley Dene, Canterbury over five growth seasons. The error bar is SEM for total spring DM yield.

Year 3 was the only year where feed on offer differed among pasture treatments with $25 \%$ more $(\mathrm{P}<0.01) \mathrm{DM}$ produced by the Luc/CF pasture compared with the $3010 \pm 321 \mathrm{~kg} \mathrm{DM} / \mathrm{ha}$ on offer from the Luc and Luc/ Brome.

\section{Lucerne DM on offer in spring}

Despite the lack of difference in total spring feed on offer in most years, there were distinct differences in composition among treatments throughout the experiment. In Year 1, lucerne in the Luc and Luc/ CF pastures totalled $4440 \pm 199 \mathrm{~kg} \mathrm{DM} / \mathrm{ha}$. This was $26 \%$ more $(\mathrm{P}<0.01)$ than the $3520 \mathrm{~kg}$ lucerne $\mathrm{DM} /$ ha produced by the Luc/Brome pasture over the same period. Lucerne yield was highest $(5245 \pm 230 \mathrm{~kg} \mathrm{DM} /$ ha) in Year $2(2013 / 14)$. In Years 3, 4 and 5, spring lucerne yields were consistently superior from the lucerne monoculture compared with those in the Luc/ grass mixes. In Year $3(2014 / 15)$, the $2235 \mathrm{~kg}$ lucerne $\mathrm{DM} /$ ha on offer in the Luc pasture was $77 \%$ greater $(\mathrm{P}<0.1)$ than the $1265 \pm 289 \mathrm{~kg}$ lucerne $\mathrm{DM} /$ ha produced in Luc/grass mixes. By Year 4 (2015/16), the magnitude of the lucerne yield difference in spring had increased with the $4040 \mathrm{~kg} \mathrm{DM} / \mathrm{ha}$ from Luc monocultures 1.6 times more $(\mathrm{P}<0.001)$ than that on offer in the Luc/ grass mixes. In the final year (2016/17), the $3235 \mathrm{~kg}$ lucerne $\mathrm{DM} /$ ha produced in the monoculture was 2.3 times more $(\mathrm{P}<0.001)$ than the $970 \pm 219 \mathrm{~kg} / \mathrm{ha}$ in the Luc/grass mixes which had become more grass (Luc/ $\mathrm{CF}$ ) or weed (Luc/Brome) dominant over time.

\section{Companion grass yield in the Luc/grass mixes}

As expected, in Year $1(2012 / 13)$ the faster establishing brome had produced $1180 \mathrm{~kg} \mathrm{DM} / \mathrm{ha}$ which was $65 \%$ more $(\mathrm{P}<0.10)$ than the $715 \mathrm{~kg} \mathrm{DM} /$ ha produced by the cocksfoot in the Luc/CF mix. In Year 2 (20013/14), 


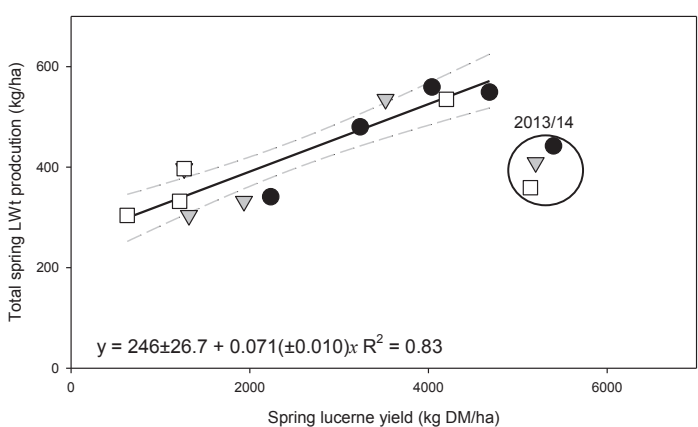

Figure 4 Net total spring liveweight (LWt) production (kg/ha) against total spring lucerne yield in Luc $(\bullet)$, Luc/ Brome $(\nabla)$ and Luc/CF ( $\square$ ) pastures between 2012/13 and 2016/17 at Ashley Dene, Canterbury. Note: 2013/14 data (circled) was excluded from analysis due to poor livestock performance resulting from foot scald.

grasses produced $595 \pm 61.0 \mathrm{~kg} \mathrm{DM} / \mathrm{ha}$ and showed no treatment effect. However, in Year 3, cocksfoot began to dominate when first exposed to water stress. The $1855 \mathrm{~kg}$ cocksfoot DM/ha was almost double $(\mathrm{P}<0.001)$ the $970 \mathrm{~kg} \mathrm{DM} / \mathrm{ha}$ from brome. Similarly, in Year $4(2015 / 16)$, there was $129 \%$ more $(\mathrm{P}<0.01)$ cocksfoot on offer in spring compared with the sown grass on offer in Luc/Brome pastures ( $840 \mathrm{~kg} \mathrm{DM} / \mathrm{ha})$. Similarly, in Year 5 (2016/17), the $2500 \mathrm{~kg}$ cocksfoot $\mathrm{DM} /$ ha was again almost double $(\mathrm{P}<0.10)$ the 1280 $\mathrm{kg}$ brome/ha on offer during the lactation phase in the Luc/Brome pastures.

\section{Weeds}

The pattern in companion grass contributions was inversely proportional to the emerging pattern in weed yields from Year $3(2014 / 15)$ onwards. Specifically, in spring of Year 3, weeds contributed $310 \pm 115 \mathrm{~kg} \mathrm{DM} /$ ha to total DM yield in the spring period. However, by Year $4(2015 / 16)$, the weed content in the Luc/Brome pasture was $1530 \mathrm{~kg} \mathrm{DM} /$ ha compared $(\mathrm{P}<0.001)$ with only $255 \mathrm{~kg} \mathrm{DM} / \mathrm{ha}$ in the Luc and Luc/CF pastures. Similarly, in the final spring (2016/17), unsown weed species accounted for $2310 \pm 523 \mathrm{~kg} \mathrm{DM} / \mathrm{ha}$ in the Luc/ Brome pasture compared $(\mathrm{P}<0.05)$ with only $250 \mathrm{~kg}$ $\mathrm{DM} / \mathrm{ha}$ in the Luc and Luc/CF pastures.

\section{Relationship between spring LWt production and lucerne on offer}

Based on differences in botanical composition, particularly lucerne yield, the relationship between LWt production and spring lucerne yields was examined (Figure 4). It showed net spring LWt (ewes + lambs) was produced at $246 \pm 26.7 \mathrm{~kg} \mathrm{LWt} / \mathrm{ha}+71.0 \pm 0.9$ $\mathrm{kg}$ LWt produced per $\mathrm{t}$ lucerne on offer $\left(\mathrm{R}^{2}=0.83\right)$ regardless of pasture type.

\section{Discussion}

For drought prone dryland farms where the majority of profit is determined by production in spring, the lucerne stands should be kept pure to maximise net LWt production. The failure of total DM yield in spring, regardless of pasture treatment, to explain variations in LWt production over the course of this five-year experiment (Figure 2) differs from work published previously (Mills et al. 2015), which showed a strong relationship between total DM yield and LWt production on a range of grass-dominant pastures and a lucerne monoculture. However, in these previously published relationships, pastures with lower total DM yields were associated with lower contributions from the companion legume resulting in less LWt production annually. Thus, relationships based on total annual DM yield may have masked the importance of the legume contribution to spring LWt production.

These results showed the inclusion of a companion grass did not usually result in differences in total spring feed on offer to grazing livestock (Figure 3). This was shown by the poor correlation between total feed on offer and net spring LWt production (Figure 2). However, changes in botanical composition were specifically related to the decline in lucerne over time in the mixes (Figure 3). This did affect the quantity of spring LWt produced (Figure 4). Cocksfoot is recognised for its competitive behaviour towards companion species (Lee \& Cho 1985; Mills et al. 2014). In this experiment, once established, cocksfoot suppressed both the lucerne yield on these light soils, and weed encroachment. In contrast, the lack of persistence of the brome, particularly in dryland environments that experience periodic water stress, was initially beneficial for the lucerne. The open gaps in the sward were compensated for by the existing lucerne. However, bare ground in the Luc/Brome pasture was colonised by weed species from Year 3, and by Year 5 weeds accounted for $41 \%$ of spring DM compared with $<5 \%$ in the Luc/CF pasture (Figure 3). Kemp et al. (1999) previously reported 'Atom' prairie grass was less persistent than other temperate grasses because of loss of plants in summer months.

Composition of the mixtures in Years 1 and 2 indicated they still have potential in commercial systems. The development of foot scald in Year 2 resulted in lower than expected LWt production. Based on a lucerne yield of $5245 \mathrm{~kg} \mathrm{DM} / \mathrm{ha}$ on offer, the relationship in Figure 4 would suggest $620 \mathrm{~kg} \mathrm{LWt} / \mathrm{ha}$ could have been produced. Overall, the results suggest Luc/grass mixes have potential for short-term use in dryland operations where overdrilling runout lucerne stands could extend the commercial life of the stand for 1-2 years without negatively impacting LWt production. Due to changes in the quantity of lucerne on offer they may be best 
suited as introductory feed sources to stock moving to lucerne after time on lower quality feed sources over the winter/late pregnancy and early lactation phases. Thus, the choice of whether to use a companion species with lucerne will ultimately depend on the purpose of the pasture. The lucerne monoculture maximised spring LWt gain, the lucerne/brome provided a suitable companion for 2-3 years, while cocksfoot dominated lucerne and minimised weeds after 3 years.

\section{Conclusions/Practical implications/ Relevance}

- Total feed on offer in spring did not explain variations in the quantity of net $\mathrm{LWt}$ produced $\left(\mathrm{R}^{2}\right.$ $=0.11)$. However, the relationship between spring LWt production and the quantity of lucerne feed on offer accounted for $83 \%$ of the observed variation. Liveweight was produced at a rate equivalent to 246 $+71 \mathrm{~kg} \mathrm{LWt}$ per tonne of lucerne feed on offer during the spring lactation phase.

- Lucerne contributions within the Luc/grass mixtures declined from Year 3.

- In the Luc/Brome pastures the loss of brome following spring drought in Year 3 was associated with subsequent increases in the yield of unsown weed species which reached $41 \%$ by Year 5 .

- Weeds did not invade the cocksfoot-based mixes, which suggests the loss of the lucerne component was due to increased competition from the cocksfoot.

\section{ACKNOWLEDGEMENTS}

This experiment was part of Phase II of the Pastoral 21 Programme, funded by the Ministry for Business, Innovation \& Employment; DairyNZ; Beef + Lamb NZ; and Fonterra, and Ministry for Primary Industries, Sustainable Farming Fund. Additional support was provided by Beef + Lamb New Zealand (Hill country Biodiversity in forage landscapes: Project 18LU01) and Mr Roland Stead.

\section{REFERENCES}

Cullen NA. 1960. Lucerne-Grass mixtures. Proceedings of the New Zealand Grassland Association 22: 122129.
Fraser TJ. 1982. Evaluation of 'Grasslands Matua' prairie grass and 'Grasslands Maru' phalaris with or without lucerne in Canterbury. New Zealand Journal of Experimental Agriculture 10: 235-237.

Kemp PD, Matthew C, Lucas RJ. 1999. Pasture Species and Cultivars. In: White J, Hodgson J Eds. New Zealand Pasture and Crop Science, pp. 83-99. Auckland: Oxford University Press.

Lee HJ, Cho MJ. 1985. Root competition and productivity in mono- and binary association of four forage species. Proceedings of the XV International Grassland Congress, August 24-31, Kyoto, Japan: 663-665.

McLenaghen R, Webb TH. 2012. Soil properties and fertility of Ashley Dene: the challenge. In: Lucas RJ, Gow N, Nichol A Ed. Ashley Dene Lincoln University Farm: the first 100 years, pp. 17-22. Christchurch: Lincoln University.

Mills A, Lucas RJ, Moot DJ. 2014. 'MaxClover' Grazing Experiment: I. Annual yields, botanical composition and growth rates of six dryland pastures over nine years. Grass and Forage Science 70: 557-570.

Mills A, Lucas RJ, Moot DJ. 2015. 'MaxClover' Grazing Experiment. II. Sheep liveweight production from six grazed dryland pastures over eight years. New Zealand Journal of Agricultural Research 58: 57-77.

Moot DJ, Smith MC, Mills A. 2019. Liveweight and dry matter yield from dryland lucerne and lucerne/ grass mixes. New Zealand Journal of Agricultural Research. https://doi.org/10.1080/00288233.002820 19.1645703

O'Connor KF. 1967. Lucerne-grass associations under different sowing and defoliation systems. In: Langer RHM Ed. The Lucerne Crop, pp. 163-176 Wellington: A.H. \& A.W. Reed.

Stevens DR, Thompson BR, Carruthers A, Wall AJ, Casey MJ, Phiskie R, Young P, Moot DJ. 2012. Understanding the role of spring grazing of lucerne in the Central Otago environment. Proceedings of the New Zealand Grassland Association 74: 69-75.

Vartha EW. 1967. Lucerne overdrilled with grasses for grazing. In: Langer RHM Ed. The Lucerne Crop, pp. 177-185 Wellington: A.H. \& A.W. Reed. 
